\title{
FACTORS AFFECTING SUPPLY CHAIN MANAGEMENT IN MOROCCAN MANUFACTURING FIRMS
}

\author{
Prof. Cheng Guoping ${ }^{1 *}$, Karroumi Hanane ${ }^{2}$ \\ *l School of Management Wuhan University of Technology, Wuhan, China \\ ${ }^{2}$ Doctoral student School of Management Wuhan University of Technology, Wuhan, China \\ Karroumi.hanane@gmail.com
}

*Corresponding Author: -

\begin{abstract}
: -
The goal of this research is to test the main factors which affect the chain management in Moroccan manufacturing firms through concentrate on morocco Distilleries firms. furthermore, this research aimed to set supply chain management used by morocco Distilleries firms, define the effectiveness of supply chain management practices at morocco Distilleries firms and determine factors affecting supply chain management at morocco Distilleries firms. The result find that the Supply chain management in Moroccan industrial firms was effectively practiced. The constructs ranked high or identified to be frequently used in supply chain practiced were: planning for supply chain, supplier(s) relationship management, manufacturing flow management, product development management, customer service management, order fulfilment, and audit performance of supply chain. Moreover, the study find that the supply chain management in Moroccan industrial firms was very effective and well performing. All seven studied instruments for measuring effectiveness of the said management. The instruments were selection of supplier(s), purchasing, transporting, manufacturing, stocking, warehousing and distribution. These were positive and significant at the 5\% level of significance.
\end{abstract}

Keywords: - Supply Chain; Relationships with Supplier; Relationships with Customer; Internal Processes; Operational Performance. 


\section{INTRODUCTION}

The goal of this research is to test the main factors which affect the chain management in Moroccan manufacturing firms through concentrate on morocco Distilleries firms. furthermore, this research aimed to set supply chain management used by morocco Distilleries firms, define the effectiveness of supply chain management practices at morocco Distilleries firms and determine factors affecting supply chain management at morocco Distilleries firms. Hakanson (2009) indicate that supply chain include of all inter linked resources and activities required to generate and deliver services and products to customers supply chain management is the process of managing supply and demand, sourcing raw materials and parts, manufacturing and assembly, distribution across all channels, and delivery to the customer.

This study concentrate on the topics related to evaluation the current and potential supplier's environment practices, the economic- environment benefits and weaknesses of foundation green supply chain and reverse logistics. Furthermore, this study concentrate on the upstream portion of the supply chain and the changes in the entire supply chain and operations strategy that result from using recycled versus virgin materials. However, this study is relevant to all firms for which the use of recycled materials is a viable option.

The main aim of this research was to test factors affecting supply chain management in manufacturing companies. The study was lead to the following specific aims;

1. To test supply chain management practices used by morocco Distilleries firms.

2. To estimate the effectiveness of supply chain management at morocco Distilleries firms.

3. To identify factors affecting implementation of supply chain strategies at morocco Distilleries firms.

This study is tried to answer the main question: "What are the factors affecting supply chain management in manufacturing companies in morocco Distilleries firms?" And to answer the following sub-questions;

1. What are supply chain management practices used by morocco Distilleries firms?

2. How effective is supply chain management at morocco Distilleries firms?

3. What are the challenges faced by morocco Distilleries firms in implementing supply chain strategies?

This research will serve as a guideline to all stakeholders in the procurement profession and manufacturing industry in morocco Distilleries firms to establish supply chain management practices used by morocco Distilleries firms, the effectiveness of supply chain management at the company factors that hinder implementation of supply chain management at the company.

The findings of the study will also serve as a stepping stone for future researchers on the same or similar topics by suggesting areas that need further studies to be conducted.

\section{Literature Review}

The objective of supply chain management is to ensure that the product is delivered at the right time and in place by optimizing existing inventories (Heizer, Render, 2014, Slack et al., 2013). Inventory management (including raw materials, work in progress and final products) can significantly influence the overall performance of the supply chain (McCormack et al., 2012). Supply chain performance can be assessed on a combination of factors using the value chain, customer and shareholder value chain (SCOR) model of supply chain operations (Bolstorff, Rosenbaum , 2007). The SCOR model considers general factors in the supply chain, but may be developed based on the need for evaluation (Guritno, 2013).

The key success factors are all the tasks that are performed, surely guaranteeing a successful manager, organization and supply chain. These factors look for this category of MSC (Supply Chain Management) that require special attention and continue to improve performance. Industry studies suggest the key issues of success vary according to (Muhammadi Zanjirani, 2007).

One of the new models of network economics is Supply Chain Management, which is a collection of methods for managing and coordinating an entire chain (from suppliers to customers) (Gowen, William, 2003) . From 1960 to 1970, companies had to improve the details of their marketing strategies based on the creation, capture and preservation of customers. They also had to participate in managing a network of all previous companies, who prepared the inputs (directly or indirectly) and all of the following companies (who were responsible for the delivery of products and aftersales services). Therefore, the notion of "supply chain" has emerged (Soleymani Shiri, 2009).

In a study by Kazzazi et al. (2012), a new technique called "a method of measuring competitiveness (service capacity) of supply chains" was proposed. This technique was designed on the basis of the lessons and indicators of the SCOR model. The six phases of this technique are: identification of factors influencing the competitiveness of supply chains using the fuzzy screening method; Determine the relative importance (weight) of the indicators selected in the first step using the fuzzy analytical hierarchical process; Determine the fuzzy value of each of the indicators selected in the first step for supply chains in the industry concerned; Classification of supply chains of concern using the fuzzy TOPSIS methodology; Finalize fuzzy values for the four main components of competitiveness; And by drawing the measures Competitiveness of each supply chain on a tetrahedron scheme (Kazzazi et al., 2012). In 2013, Jafari et al. evaluated the performance of the supply chain using the fuzzy hierarchical analytical method. They used the fuzzy decision-making approach to prioritize the criteria and determine the importance of each criterion for the overall performance of the supply chain. They used five indicators (planning, supply of resources, production, delivery 
and performance) as major criteria and finally an appropriate model and method for decision-making and performance evaluation A complete supply chain (Mahnaz, et al., 2014). Aqajani and Dargahi (2012) conducted a study to evaluate and select suppliers to prepare a protection part for Iran Khodro Company. They located the selected indicators and Classified as 12 factors or assessment criteria. Then, using the analytical hierarchy process (AHP), they weighted the indicators and finally using the Vikor technique ranked the suppliers (Aqajani \& Dargahi, 2012). In their research, Ismaelian and Rabiyi (2007) introduced a vague decision-making process for the problems of supplier selection in supply chains. They considered the most appropriate vendor identification as a strategic factor in supply chains. They also considered many qualitative and quantitative performance criteria (such as quality, price, flexibility and delivery time) to determine the most appropriate supplier. He also used the Multi-Criteria Decision Making (MCDM) method in the blur environment to select the appropriate provider. They used three methods for weight calculation and option classification using the fuzzy TOPSIS technique (Ismaelian, Rabiyi, 2007).

\section{Methodology Study Model}

Figure 1 shows the study conceptual framework. The left side showed the independent variable which include; transportation cost, road infrastructure and logistics management. Moreover, the right side shows the dependent variable which include; cost efficiency, timely delivery and proper storage.

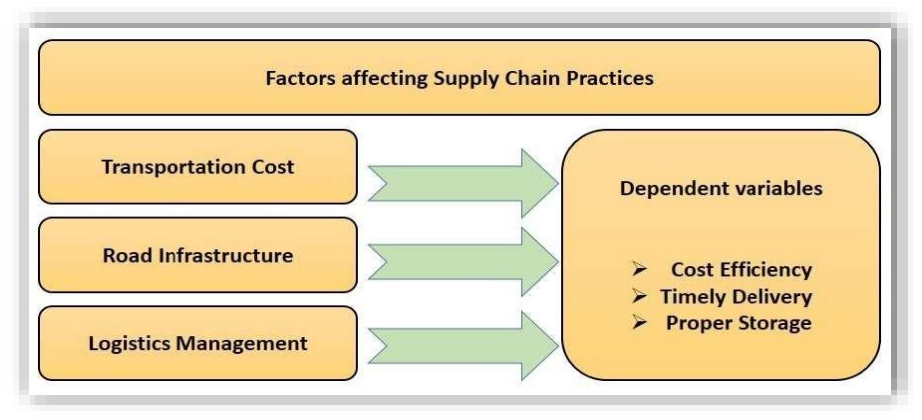

Figure 1: shows the study conceptual framework

\section{Study population, sample, Sample procedure and Study instrument}

This study rely on descriptive research design by applying cross sectional data. Because the nature of this study which is a comprehensive description. Moreover, applying the case study research allow to conduct an extensive investigation of the Supply Chain Management System used by morocco Distilleries firms, it is effectiveness and factors that affect it is effectiveness. This research was conducted in morocco head Offices of morocco Distilleries firms located. The researcher met respondents of the study who are in one way or another involved in supply chain management activities at morocco Distilleries firms.

The population of this research include all of members of staff of morocco Distilleries firms who are involved in supply chain management activities. In this research we used purposive sampling way to choose a sample size of 60 respondents out of 2400. the research sample contain 4 members from the management staff, 10 members from supplying department, 12 member from store keeping department, 14 member from marketing department, 7 member from transportation department and 13 member from sales department. All the sample size selects relying on the statistical formula. This research applies to both primary and secondary primary. Documentary sources, journals, articles, official publications, newspaper clippings, reports and seminar materials were used to present the facts and justification of the arguments in order to secure the secondary data. In the primary data, interviews, questionnaires, photographs and observation were used to collect data.

This research apply two kind of interviews with the members of the management team of morocco Distilleries firms which is structured and unstructured interviews. we used interviews because it allow to meet respondent face to face and its easy and simple way to collect data which allow to provides straight answers to research questions. Through interviews, the researcher collected information on the supply chain management system used by morocco Distilleries firms, how effective the system is and factors that affect the system. Observation is a data collection way that include seeking information by the way of environment scanning (Kothari, 2006). This study applied observation method to find out how morocco Distilleries firms implements its supply chain management system, how effective the system is, factors that affect the system, and measures taken to improve it.

\section{Study sample characteristics}

Table (1) shows the study sample according to the gender

\begin{tabular}{|c|c|c|c|c|c|c|c|}
\hline & management & $\begin{array}{c}\text { supplying } \\
\text { department }\end{array}$ & $\begin{array}{c}\text { store } \\
\text { keeping }\end{array}$ & $\begin{array}{c}\text { marketing } \\
\text { department }\end{array}$ & $\begin{array}{c}\text { transportation } \\
\text { department }\end{array}$ & $\begin{array}{c}\text { sales } \\
\text { department }\end{array}$ & Total \\
\hline Male & 3 & 7 & 8 & 10 & 6 & 11 & 45 \\
\hline & 0.75 & 0.700 & 0.667 & 0.714 & 0.857 & 0.846 & 0.75 \\
\hline Female & 1 & 3 & 4 & 4 & 1 & 2 & 15 \\
\hline$\%$ & 0.25 & 0.300 & 0.333 & 0.286 & 0.143 & 0.154 & 0.25 \\
\hline \multirow{2}{*}{ Total } & 4 & 10 & 12 & 14 & 7 & 13 & 60 \\
\cline { 2 - 9 } & $100 \%$ & $100 \%$ & $100 \%$ & $100 \%$ & $100 \%$ & $100 \%$ & 100 \\
\hline
\end{tabular}


Table (1) shows that $75 \%$ of the study respondent are male while $25 \%$ are female. Moreover, we find that $75 \%$ of the study respondent in the management section are male while $25 \%$ are female. In addition, in supplying department we find that $70 \%$ of the study sample are male while $30 \%$ are female. Furthermore, in store department we find that $66.7 \%$ are male while $33.3 \%$ are female. While, in marketing department $71.4 \%$ of the study respondent are make and $28.6 \%$ are female. Moreover, in transportation department $85.7 \%$ of the study respondent are male while $24.3 \%$ are female. Finally, in sales department $84.6 \%$ of the study respondent are male while $15.4 \%$ are female.

Table (2) shows the study sample according to age

\begin{tabular}{|c|c|c|c|c|c|c|c|}
\hline Sec. & $\begin{array}{c}\text { managemne } \\
\text { nt }\end{array}$ & $\begin{array}{l}\text { supplying } \\
\text { department }\end{array}$ & $\begin{array}{r}\text { store } \\
\text { keepin }\end{array}$ & $\begin{array}{c}\text { marketing } \\
\text { departmen } \\
\mathrm{t}\end{array}$ & $\begin{array}{l}\text { transportati } \\
\text { on } \\
\text { department }\end{array}$ & $\begin{array}{c}\text { sales } \\
\text { departmen } \\
t\end{array}$ & $\begin{array}{c}\text { Tot } \\
\text { al }\end{array}$ \\
\hline $\begin{array}{c}\text { Less } \\
\text { than } 30 \\
\text { year }\end{array}$ & 2 & 6 & 7 & 9 & 4 & 8 & 36 \\
\hline $\begin{array}{l}\% \text { within } \\
\text { group }\end{array}$ & 0.056 & 0.167 & $\begin{array}{c}0.19 \\
4\end{array}$ & 0.250 & 0.111 & 0.222 & $\begin{array}{c}1.00 \\
0\end{array}$ \\
\hline $\begin{array}{c}\% \text { with } \\
\text { total }\end{array}$ & 0.033 & 0.100 & $\begin{array}{c}0.11 \\
7\end{array}$ & 0.150 & 0.067 & 0.133 & $\begin{array}{c}0.60 \\
0\end{array}$ \\
\hline $31-50$ & 1 & 3 & 2 & 3 & 1 & 3 & 13 \\
\hline $\begin{array}{l}\text { \% within } \\
\text { group }\end{array}$ & 0.077 & 0.231 & $\begin{array}{c}0.15 \\
4\end{array}$ & 0.231 & 0.077 & 0.231 & $\begin{array}{c}1.00 \\
0\end{array}$ \\
\hline $\begin{array}{c}\% \text { with } \\
\text { total }\end{array}$ & 0.017 & 0.050 & $\begin{array}{c}0.03 \\
3\end{array}$ & 0.050 & 0.017 & 0.050 & $\begin{array}{c}0.21 \\
7\end{array}$ \\
\hline $\begin{array}{l}\text { More } \\
\text { than } 51\end{array}$ & 1 & 1 & 3 & 2 & 2 & 2 & 11 \\
\hline $\begin{array}{l}\text { \% within } \\
\text { group }\end{array}$ & 0.091 & 0.091 & $\begin{array}{c}0.27 \\
3\end{array}$ & 0.182 & 0.182 & 0.182 & $\begin{array}{c}1.00 \\
0\end{array}$ \\
\hline $\begin{array}{c}\% \text { with } \\
\text { total }\end{array}$ & 0.017 & 0.017 & $\begin{array}{c}0.05 \\
0\end{array}$ & 0.033 & 0.033 & 0.033 & $\begin{array}{c}0.18 \\
3\end{array}$ \\
\hline Total & 4 & 10 & 12 & 14 & 7 & 13 & 60 \\
\hline total $\%$ & 0.067 & 0.167 & 0.20 & 0.233 & 0.117 & 0.217 & 1.00 \\
\hline
\end{tabular}

Table (2) shows the study sample according to age, we note that $60 \%$ of the study sample are less than 30 years old. In addition management represent $5.6 \%$ of the study sample within group and $3.3 \%$ within total. Moreover, supplying department represent $16.7 \%$ within the group and $10 \%$ within total. Furthermore, store keeping department represent $19.4 \%$ within the group and $11.7 \%$ within total. Additionally, marketing department represent $25 \%$ within the group and $15 \%$ within total. Also. Transportation department represent $11.1 \%$ within the group and $6.7 \%$ within total. Finally, sales department represent $22.2 \%$ within the group and $13.3 \%$ within total. We note also that $21.7 \%$ of the study sample are between 31- 50 years old. In addition management represent $7.7 \%$ of the study sample within group and $1.7 \%$ within total. Moreover, supplying department represent $23.1 \%$ within the group and 5\% within total. Furthermore, store keeping department represent $15.4 \%$ within the group and $3.3 \%$ within total. Additionally, marketing department represent $23.1 \%$ within the group and $5 \%$ within total. Also. Transportation department represent $7.7 \%$ within the group and $1.7 \%$ within total. Finally, sales department represent $23.1 \%$ within the group and $5 \%$ within total. We note that $18.3 \%$ of the study sample are more than 50 years old. In addition management represent $9.1 \%$ of the study sample within group and $1.7 \%$ within total. Moreover, supplying department represent $9.1 \%$ within the group and $1.7 \%$ within total. Furthermore, store keeping department represent $27.3 \%$ within the group and $5 \%$ within total. Additionally, marketing department represent $18.2 \%$ within the group and $3.3 \%$ within total. Also. Transportation department represent $18.2 \%$ within the group and $3.3 \%$ within total. Finally, sales department represent $18.2 \%$ within the group and $3.3 \%$ within total. 
Table (3) shows the study sample according to education

\begin{tabular}{|c|c|c|c|c|c|c|c|}
\hline Sec. & management & $\begin{array}{c}\text { supplying } \\
\text { department }\end{array}$ & $\begin{array}{c}\text { store } \\
\text { keeping }\end{array}$ & $\begin{array}{c}\text { marketing } \\
\text { department }\end{array}$ & $\begin{array}{c}\text { transportation } \\
\text { department }\end{array}$ & $\begin{array}{c}\text { sales } \\
\text { department }\end{array}$ & Total \\
\hline $\begin{array}{c}\text { High } \\
\text { education }\end{array}$ & 1 & 1 & 0 & 1 & 0 & 0 & 3 \\
\hline $\begin{array}{l}\text { \% within } \\
\text { group }\end{array}$ & $\begin{array}{c}0.33 \\
3\end{array}$ & 0.333 & $\begin{array}{c}0.00 \\
0\end{array}$ & 0.333 & 0.000 & 0.000 & 1.000 \\
\hline $\begin{array}{c}\% \text { with } \\
\text { total }\end{array}$ & $\begin{array}{c}0.01 \\
7\end{array}$ & 0.017 & $\begin{array}{c}0.00 \\
0\end{array}$ & 0.017 & 0.000 & 0.000 & 0.05 \\
\hline bachelor & 1 & 4 & 4 & 5 & 2 & 6 & 22 \\
\hline $\begin{array}{l}\text { \% within } \\
\text { group }\end{array}$ & $\begin{array}{c}0.04 \\
5\end{array}$ & 0.182 & $\begin{array}{c}0.18 \\
2\end{array}$ & 0.227 & 0.091 & 0.273 & 1.000 \\
\hline $\begin{array}{c}\% \text { with } \\
\text { total }\end{array}$ & $\begin{array}{c}0.01 \\
7\end{array}$ & 0.067 & $\begin{array}{c}0.06 \\
7\end{array}$ & 0.083 & 0.033 & 0.100 & 0.367 \\
\hline $\begin{array}{l}\text { less than } \\
\text { bachelor }\end{array}$ & 2 & 5 & 8 & 8 & 5 & 7 & 35 \\
\hline $\begin{array}{l}\text { \% within } \\
\text { group }\end{array}$ & $\begin{array}{c}0.05 \\
7\end{array}$ & 0.143 & $\begin{array}{c}0.22 \\
9\end{array}$ & 0.229 & 0.143 & 0.200 & 1.000 \\
\hline $\begin{array}{c}\% \text { with } \\
\text { total }\end{array}$ & $\begin{array}{c}0.03 \\
3\end{array}$ & 0.083 & $\begin{array}{c}0.13 \\
3\end{array}$ & 0.133 & 0.083 & 0.117 & 0.583 \\
\hline total & 4 & 10 & 12 & 14 & 7 & 13 & 60 \\
\hline total $\%$ & $\begin{array}{c}0.06 \\
7 \\
\end{array}$ & 0.167 & $\begin{array}{c}0.20 \\
0\end{array}$ & 0.233 & 0.117 & 0.217 & 1.000 \\
\hline
\end{tabular}

Table (3) shows the study sample according to education, we note that $5 \%$ of the study sample are high education. In addition, management represent $33.3 \%$ of the study sample within group and $1.7 \%$ within total. Moreover, supplying department represent $33.3 \%$ within the group and $1.7 \%$ within total. Furthermore, store keeping department represent $0 \%$ within the group and $0 \%$ within total. Additionally, marketing department represent $33.3 \%$ within the group and $1.7 \%$ within total.

Also. Transportation department represent $0 \%$ within the group and $0 \%$ within total. Finally, sales department represent $0 \%$ within the group and $0 \%$ within total. We note also that $36.7 \%$ of the study sample are bachelor. In addition, management represent $4.5 \%$ of the study sample within group and $1.7 \%$ within total. Moreover, supplying department represent $18.2 \%$ within the group and $6.7 \%$ within total. Furthermore, store keeping department represent $18.2 \%$ within the group and $6.7 \%$ within total. Additionally, marketing department represent $22.7 \%$ within the group and $8.3 \%$ within total. Also. Transportation department represent $9.1 \%$ within the group and $3.3 \%$ within total. Finally, sales department represent $27.3 \%$ within the group and $10 \%$ within total. We note that $58.3 \%$ of the study sample are less than bachelor. In addition management represent $5.7 \%$ of the study sample within group and $3.3 \%$ within total. Moreover, supplying department represent $14.3 \%$ within the group and $8.3 \%$ within total. Furthermore, store keeping department represent $22.9 \%$ within the group and $13.3 \%$ within total. Additionally, marketing department represent $22.9 \%$ within the group and $13.3 \%$ within total. Also. Transportation department represent $14.3 \%$ within the group and $8.3 \%$ within total. Finally, sales department represent $20 \%$ within the group and $11.7 \%$ within total. 
Table (4) shows the study sample according to experience

\begin{tabular}{|c|c|c|c|c|c|c|c|}
\hline Sec. & $\begin{array}{c}\text { managem } \\
\text { ent }\end{array}$ & $\begin{array}{l}\text { supplying } \\
\text { department }\end{array}$ & $\begin{array}{l}\text { store } \\
\text { keepin } \\
\mathrm{g}\end{array}$ & $\begin{array}{c}\text { marketin } \\
\mathrm{g} \\
\text { departme } \\
\mathrm{nt}\end{array}$ & $\begin{array}{l}\text { transportati } \\
\text { on } \\
\text { department }\end{array}$ & $\begin{array}{c}\text { sales } \\
\text { departme } \\
\text { nt }\end{array}$ & $\begin{array}{c}\text { Tot } \\
\text { al }\end{array}$ \\
\hline $\begin{array}{l}\text { Less than } \\
5 \text { years }\end{array}$ & 2 & 3 & 4 & 4 & 2 & 5 & 20 \\
\hline $\begin{array}{r}\% \\
\text { within }\end{array}$ & 0.100 & 0.150 & $\begin{array}{c}0.2 \\
00\end{array}$ & 0.200 & 0.100 & 0.250 & $\begin{array}{l}1.0 \\
00\end{array}$ \\
\hline$\%$ with total & 0.033 & 0.050 & 0.0 & 0.067 & 0.033 & 0.083 & 0.3 \\
\hline $\begin{array}{c}\text { Between 5- } \\
10\end{array}$ & 1 & 4 & 4 & 4 & 3 & 4 & 20 \\
\hline $\begin{array}{r}\% \\
\text { within }\end{array}$ & 0.050 & 0.200 & $\begin{array}{l}0.2 \\
00\end{array}$ & 0.200 & 0.150 & 0.200 & $\begin{array}{l}1.0 \\
00\end{array}$ \\
\hline$\%$ with total & 0.017 & 0.067 & $\begin{array}{c}0.0 \\
67 \\
\end{array}$ & 0.067 & 0.050 & 0.067 & $\begin{array}{l}0.3 \\
33 \\
\end{array}$ \\
\hline $\begin{array}{l}\text { More than } \\
10 \text { years }\end{array}$ & 1 & 3 & 4 & 6 & 2 & 4 & 20 \\
\hline $\begin{array}{r}\% \\
\text { within } \\
\end{array}$ & 0.050 & 0.150 & $\begin{array}{c}0.2 \\
00\end{array}$ & 0.300 & 0.100 & 0.200 & $\begin{array}{l}1.0 \\
00\end{array}$ \\
\hline$\%$ with total & 0.017 & 0.050 & $\begin{array}{c}0.0 \\
66 \\
\end{array}$ & 0.100 & 0.033 & 0.067 & $\begin{array}{l}0.3 \\
33 \\
\end{array}$ \\
\hline total & 4 & 10 & 12 & 14 & 7 & 13 & 60 \\
\hline total $\%$ & 0.067 & 0.167 & $\begin{array}{c}0.2 \\
00 \\
\end{array}$ & 0.233 & 0.117 & 0.217 & $\begin{array}{l}1.0 \\
00 \\
\end{array}$ \\
\hline
\end{tabular}

Table (4) shows the study sample according to experience, we note that $33.3 \%$ of the study sample have experience less than five years. In addition management represent $10 \%$ of the study sample within group and $3.3 \%$ within total. Moreover, supplying department represent $15 \%$ within the group and 5\% within total. Furthermore, store keeping department represent $20 \%$ within the group and $6.7 \%$ within total. Additionally, marketing department represent $20 \%$ within the group and $6.7 \%$ within total. Also. Transportation department represent $10 \%$ within the group and $3.3 \%$ within total. Finally, sales department represent $25 \%$ within the group and $8.3 \%$ within total. We note also that $33.3 \%$ of the study sample have experience between 5 -10 years. In addition management represent 5\% of the study sample within group and $1.7 \%$ within total. Moreover, supplying department represent $20 \%$ within the group and $6.7 \%$ within total. Furthermore, store keeping department represent $20 \%$ within the group and $6.7 \%$ within total. Additionally, marketing department represent $20 \%$ within the group and $6.7 \%$ within total. Also. Transportation department represent $15.5 \%$ within the group and 5\% within total. Finally, sales department represent $20 \%$ within the group and $6.70 \%$ within total. We note that $33.3 \%$ of the study sample have experience more than 10 years. In addition management represent $5 \%$ of the study sample within group and $1.7 \%$ within total. Moreover, supplying department represent $15 \%$ within the group and 5\% within total. Furthermore, store keeping department represent $20 \%$ within the group and $6.6 \%$ within total. Additionally, marketing department represent $30 \%$ within the group and $10 \%$ within total. Also. Transportation department represent $10 \%$ within the group and $3.3 \%$ within total. Finally, sales department represent $20 \%$ within the group and $6.7 \%$ within total.

\section{Results Discussion}

In this study we test the supply chain management practices used by Moroccan firms. Therefore, this study used variables related to supply chain management practices in an organization to examine how the responders perceived application of the given variables in the management of supply chain in Moroccan firms. The variables were planning for supply chain, supplier(s) relationship management, manufacturing flow management, product development management, customer service management, demand management, order fulfilment, return management and audit performance of supply chain. This study used Likert scale ranging from strongly disagree (1) to strongly agree (4). To calculate the supply chain management practices we used the means and Chi-square values. Furthermore, applying the mean scores and Chi-squire describe the strengths and weaknesses of the supply chain management variables. 
Table (5) shows the ANOVA's summary for the Supply Chain Management Practices.

\begin{tabular}{|c|c|c|c|c|}
\hline Variable & $\mathbf{N}$ & Means & Sig. (p-value) & Interpretation \\
\hline $\begin{array}{c}\text { Supplier(s) relationship } \\
\text { management }\end{array}$ & 60 & 3.71 & 0.879 & Used Frequently \\
\hline $\begin{array}{c}\text { Manufacturing flow } \\
\text { management }\end{array}$ & 60 & 3.51 & 0.372 & Used Frequently \\
\hline $\begin{array}{c}\text { Product development } \\
\text { management }\end{array}$ & 60 & 3.63 & 0.381 & Used Frequently \\
\hline $\begin{array}{c}\text { Customer service } \\
\text { management }\end{array}$ & 60 & 3.59 & 0.110 & Used Frequently \\
\hline Demand management & 60 & 3.55 & 0.316 & Used Frequently \\
\hline Order fulfilment & 60 & 3.19 & 0.287 & Used Occasionally \\
\hline Return management & 60 & 3.46 & 0.061 & Used Frequently \\
\hline $\begin{array}{c}\text { Audit performance of } \\
\text { supplv chain }\end{array}$ & 60 & 3.15 & 0.944 & Used Rarely \\
\hline Average Mean Score & & 3.7 & 0.322 & Used Frequently \\
\hline
\end{tabular}

We note that the means for the seven construct on supply chain management: planning for supply chain, supplier(s) relationship management, manufacturing flow management, product development management, customer service management, order fulfilment, and audit performance of supply chain were: $3.71,3.51,3.63,3.59,3.55,3.46$ and 3.7 respectively, which means frequently use of constructs in management of supply chain. While the two constructs demand management and return management were rated low at means of 3.19 and 2.15 respectively, which implies occasionally use of demand management and rarely use of return management in management of supply chain. The average mean of 3.4 signifies agreement by the respondent to the effect that supply chain management was frequently practiced in Moroccan Distillers Limited.

Furthermore, the study result shows that there was no significant difference between respondents in their perception that planning for supply chain $(\mathrm{p}=0.879)$, supplier( $\mathrm{s})$ relationship management $(\mathrm{p}=0.372)$, manufacturing flow management $(\mathrm{p}=0.381)$, customer service management $(\mathrm{p}=0.316)$, product development management $(\mathrm{p}=0.110)$, demand management $(\mathrm{p}=0.287)$, and audit performance of supply chain $(\mathrm{p}=0.322)$ were used in the management of supply chain in Moroccan industrial firms, all respondent had the same view that the said constructs were frequently used/practiced in management of supply chain; the observed p-values were greater than 0.05 .

The Second aim of this study is to evaluate the efficiency Supply chain In the Moroccan industrial management companies. However, many organizations to adopt the concept of supply management to pay improving the integrated Efficiency System supply chain. It allows supply chain management organizations the opportunity to integrate the flow of resources and the entire value chain throughout the supply chain. The integration of the supply chain of the partners in disparate One Only agile action System and competitive smooth and flexible to provide may Effective products / services Unique fast, efficient and client packages each pay coefficients on request (IMA, 1999) Supply, procurement, transport, manufacturing, stocking, storage and distribution in the management of the supply chain. Was held in the Seven Likert Practical Info of going highly to disapproval and highly approve to Respondents to submit evaluate their Views Provided.

The mean scores and Chi-square values were used to calculate for the effectiveness of supply chain management. The analysis rely on the mean scores and Chi-squire reflected the degree of integration of the said instruments in terms integrated supply chain management. To interpret the obtained data, the following numerical values and interpretations were used to measure their effectiveness of supply chain management in Moroccan industrial firms. Table (6) shows the ANOVA's summary for the Effectiveness of Supply Chain Management.

Table (6) shows the ANOVA's summary for the Effectiveness of Supply Chain Management.

\begin{tabular}{|l|l|l|l|l|}
\hline \multicolumn{1}{|c|}{ Variable } & N & Means & Sig. (p-value) & Interpretation \\
\hline supplier(s) & 60 & 3.51 & 0.772 & Strongly Effective \\
\hline Purchasing & 60 & 3.68 & 0.044 & Strongly Effective \\
\hline Transporting & 60 & 3.79 & 0.001 & Strongly Effective \\
\hline Manufacturing & 60 & 3.26 & 0.038 & Effective \\
\hline Stocks & 60 & 3.64 & 0.061 & Strongly Effective \\
\hline Warehousing & 60 & 3.24 & 0.219 & Effective \\
\hline Distribution & 60 & 3.58 & 0.001 & Strongly Effective \\
\hline Average Mean Score & \multicolumn{7}{|c|}{3.545} & Strongly Effective \\
\hline
\end{tabular}

We note that all seven items for determining effectiveness of supply chain management at Moroccan industrial firms show interesting results. Wherein five items: Selection of supplier(s), purchasing, transporting, stocking, and 
distribution were rated very high at means of 3.51, 3.68, 3.79, 3.64 and 3.58 respectively, which implies strongly effectiveness. While the remaining two items manufacturing and warehousing were rated 3.26 and 3.24 respectively, this implies effective in management of supply chain. The average mean of 3.545 signifies respondents had agreed supply chain management in Moroccan industrial firms was strongly effectively used.

Furthermore, from the above effects, it can be concluded that there were integrated decisions in all seven studied instruments: selection of supplier(s), purchasing, transporting, manufacturing, stocking, warehousing and distribution. For that reason it can be, however, concluded that supply chain management in Moroccan industrial firms was very effective and well performing.

The third aim of this study is to determine factors affecting implementations of supply chain management strategies at Moroccan industrial firms. Additionally, the nine instruments aspired to identify the said issue were prepared and submitted to the respondent to give their opinions concern with matter. Questions were in the Likert scale ranging from strongly I disagree with the factor to strongly I agree with the factor in disturbing supply chain strategies.

The nine items/variables analyzed were general management incapability, employees' incapability, high management cost, low product quality performance, process and technology incapability, improper production scheduling, policies and regulatory appliance, improper distribution time management and supplier(s) misbehave. The mean scores and Chisquire values were employed to compute for the factors affecting implementations of supply chain strategies. Table (7) shows the ANOVA's summary for the Factors Affecting Supply Chain Strategies.

Table (7) shows the ANOVA's summary for the Factors Affecting Supply Chain Strategies.

\begin{tabular}{|l|l|l|l|l|}
\hline \multicolumn{1}{|c|}{ Variable } & N & Means & Sig. (p-value) & Interpretation \\
\hline General management incapability & 60 & 1.71 & 0.337 & None \\
\hline Employees incapability & 60 & 2.08 & 0.220 & Not so much \\
\hline High management cost & 60 & 3.02 & 0.632 & Some \\
\hline Low product quality performance & 60 & 1.91 & 0.044 & Not so much \\
\hline Process and technology incapability & 60 & 2.36 & 0.007 & Not so much \\
\hline Improper production scheduling & 60 & 2.72 & 0.006 & Not so much \\
\hline Policies and regulatory appliance & 60 & 2.51 & 0.115 & Nome \\
\hline $\begin{array}{l}\text { Improper distribution time } \\
\text { management }\end{array}$ & 60 & 2.18 & 0.101 & Not so much \\
\hline Supplier(s) misbehave & 60 & 2.01 & 0.746 & Not so much \\
\hline Average Mean Score & & 2.27 & \\
\hline
\end{tabular}

Table (7) presents factors causing challenges in implementation of supply chain management in Moroccan industrial firms. High management cost ranked highest with mean (3.02) which is some- how challenged. Improper production scheduling was also rated some with a mean of (2.72). The following 6 items were also rated not so much: employees' incapability (2.36), low product quality performance (1.91), process and technology incapability (2.36), policies and regulatory appliance (2.51), improper distribution time (2.18), and supplier(s) misbehave (2.01). Usually, average mean was (2.25) which is not so much. These items give an implication that challenges in implementation of supply chain management in Moroccan industrial firms is at lower level. However, it was shown that general management was effectively in ensuring planed supply chain strategies were implemented-this is why associated challenges have been rated low (not so much).

\section{Conclusions}

This study aimed to test factors affecting supply chain management in manufacturing companies by focusing on Moroccan Distilleries Limited as a cases study. This study concentrated on four specific questions which are: What are supply chain management practices used by Moroccan industrial firms? How effective is supply chain management at Moroccan industrial firms? What are the challenges faced by Moroccan industrial firms in implementing supply chain strategies? What measures should be taken to improve supply chain management at Moroccan industrial firms?

Related to supply chain management practices used by Moroccan industrial firms, there were nine constructs to be studies and the results obtained from analysis shown that the seven constructs which are planning for supply chain, supplier(s) relationship management, manufacturing flow management, product development management, customer service management, order fulfilment, and audit performance of supply chain were: $3.71,3.51,3.63,3.59,3.55,3.46$ and 3.7 respectively, which means frequently use of constructs in management of supply chain. While the two constructs demand management and return management were rated low at means of 3.19 and 2.15 respectively, which implies occasionally use of demand management and rarely use of return management in management of supply chain. The average mean was 3.4 .

Additionally, there were seven items for determining effectiveness of supply chain management at Moroccan industrial firms. The result were showing that selection of supplier(s), purchasing, transporting, stocking, and distribution were 
rated very high at means of 3.51, 3.68, 3.79, 3.64 and respectively. While the remaining two items manufacturing and warehousing were rated 3.26 and 3.24 respectively. The average mean was 3.545 signifies respondents had agreed supply chain management in Moroccan industrial firms was strongly effectively used.

Finally, the results of the challenges faced by Moroccan industrial firms in applying supply chain strategies were as follow: high management cost of supply chain and improper production scheduling were ranked high with mean of 3.02 and 2.72 respectively. While employees' incapability (2.36), low product quality performance (1.91), process and technology incapability (2.36), policies and regulatory appliance (2.51), improper distribution time (2.18), and supplier(s) misbehave (2.01) were rated low. Generally, average mean was (2.27) which imply challenges were not so much.

In summary, the study found the following results:

1. Supply chain management in Moroccan industrial firms was effectively practiced. The constructs ranked high or identified to be frequently used in supply chain practiced were: planning for supply chain, supplier(s) relationship management, manufacturing flow management, product development management, customer service management, order fulfilment, and audit performance of supply chain.

2. Supply chain management in Moroccan industrial firms was very effective and well performing. All seven studied instruments for measuring effectiveness of the said management. The instruments were selection of supplier(s), purchasing, transporting, manufacturing, stocking, warehousing and distribution. These were positive and significant at the $5 \%$ level of significance.

\section{Recommendation and Future Studies Recommendation}

To develop supply chain management practices at Moroccan industrial firms, the researcher recommends the following measures to be taken by Moroccan industrial firms:

1. Moroccan industrial firms should only consider suppliers who have demonstrated reliability by fulfilling its obligation of the contract despite any contingencies or emergencies that may arise to avoid supply management challenges arising from the supplier side.

2 Moroccan industrial firms should provide frequent training to staff members on the best practices of supply chain management in form of seminars and workshops to overcome the challenge of lack of awareness on supply management practices among some of it's staff members.

3. Moroccan industrial firms and any organization intends to achieve operational efficiency and productivity must place great importance to the management of supply chain so as to reduce inventory, increase the speed of transactions, reduce cost and eliminate waste.

4. Moroccan industrial firms should invest more on the development and training of its employees through seminars, workshops and short study courses for effectiveness and efficiency in the performance of operations and the elimination of wastes.

\section{Future Studies}

The researcher suggests the following studies in the future:

1. Expand this study to other industry in the region and in other manufacturing industries other than distillation industry.

2. Applying other variables in an organization culture hat influence supply chain management.

3. It would also be interesting to expand this study to other countries and compare the results.

\section{References}

[1].Aqajani, Hassanali \& Dargahi, Hadi. (2012). Assessing supply chain suppliers using a combined approach resulted from multi-criteria decision making techniques in the fuzzy environment. Third national conference of industrial and systems engineering.

[2].Ismaelian, Majid \& Rabiyeh Masoud. (2007). Assessment and selection of suppliers using fuzzy TOPSIS and fractional planning. Fifth national conference on industrial engineering.

[3].Bolstorff, P. and R. Rosenbaum. (2007). Supply Chain Excellence: A Handbook for Dramatic Improvement Using the SCOR Model. Amacom: New York.

[4].Mahnaz Daneshyan, Hassan Dehqan Dehnavi \& Mahmoud Moein al-Din. (2014). Ranking factors influencing supply chain performance management. International conference on management in the 21 st century.

[5].Gowen, Charles R. Tallon, and William J. (2003). Enhancing supply chain practices through human resource management, Journal of Management Development, Vol. 22 No. 1, pp. 32-44.

[6].Guritno, A. (2013). Development of supply chain risk management of fresh vegetables. Proceeding of Food Innovation Asia Conference 2013: Empowering SMEs through science and technology. Bangkok, Thailand.

[7].Heizer, J, and B. Render. (2014). Operations Management. John Wiley and Sons. Singapore.

[8].Slack, S. Chamber, \& R. Johnston. (2013). Operations Management, Pearson Ed.

[9].McCormack, K., Johnson, W., and W. Walker. (2012). Supply Chain Networks and Business Process Orientation: Advanced Strategies and Best Practices. CRC Press LLC. Boca Raton Florida.

[10]. Muhammadi Zanjirani, Duruish \& Muhammad Modarres Yazdi. (2007). an evident approach to measuring the performance of supply chain: introducing an instrument for the design and development of top supply chains in Iranian industries. Third national conference on performance management, p. 7. 
[11]. Soleymani, Shiri, Q. (2009). Supply chain with a fusion of analytical hierarchy process and idealistic planning (case study of automobile industries). Management Quarterly, no. 15.

[12]. Kazzazi, Abulfazl, Adel \& Zangouyinezhad, Abudar (2012). Measuring the competitiveness of supply chains using the fuzzy approach. Roshd University Quarterly, no. 2, pp. 55-72.

[13]. Jafari, Morteza. (2013). Applying the fuzzy TOPSIS method to the identification and ranking of factors influencing the performance of steel production companies. M.A. thesis, Islamic Azad University, Central Tehran Branch. 